\title{
GREEN GROWTH IS TRUSTED TO FIX CLIMATE CHANGE
}

\author{
Robert Skopec \\ Researcher-analyst, Dubnik, Slovakia \\ (Received on Date: 23rd April 2020 \\ Date of Acceptance: $20^{\text {th }}$ May 2020 \\ Date of Publish: $01^{\text {st }}$ July 2020) \\ Email id: zxcbnvm7@gmail.com
}

\begin{abstract}
'Greening' our current economic system can only take us so far. GTS/Shutterstock You may have missed it, but a recent report declared that the main strategy of world leaders for tackling climate change won't work. It's called green growth, and it's favoured by some of the largest and most influential organisations in the world, including the United Nations and the World Bank.
\end{abstract}

\section{Keywords}

Health effects, weather modification, rain making, silver iodide, International Space Station, the dazzling weapons, hallucinations, dizzines, nausea, disorientation, temporary blindnesss

\section{Conflict of Interests Disclosure}

The Author declares no conflict of interests. 


\section{INTRODUCTION}

Green growth is a vague term with many definitions, but broadly speaking, it's the idea that society can reduce its environmental impacts and slash its emissions, even while the economy continues to grow and the quantity of stuff that's produced and consumed increases. This would be achieved by improving the efficiency of production and manufacturing processes, transitioning to cleaner energy sources and developing new technologies to deal with the pollution that economic activity creates. Better yet, it's argued, all of this could be done fast enough to meet the Paris Agreement target of keeping global warming to below $1.5^{\circ} \mathrm{C}$. $(1,2)$

Fixing the climate crisis without having to compromise on economic growth sounds appealing. But the Decoupling Debunked report echoes work by prominent academics in finding that there is no evidence that societies have ever managed to decouple economic growth from emissions at this scale in the past, and little evidence they have the capacity to achieve it in the future. $(3,4)$

It's no surprise that, historically, global carbon emissions have gone up as economies have grown. The processes that produce the goods and services we all consume use raw materials as inputs and generate pollution, carbon emissions and waste. $(5,6)$

\section{Materials and Methods}

Making these processes more efficient and swapping fossil fuels for renewables can, and has, reduced the average emissions that come with each additional dollar of economic growth. This is known as "relative decoupling", because each dollar of new economic growth has fewer emissions attached to it, relative to each dollar of past growth. But, emissions still rise in absolute terms because the economy is still growing.

Since it is the total amount of carbon in the atmosphere that matters in the race against climate change, we need to contrast this idea of "relative decoupling" with the stronger concept of "absolute decoupling". Absolute decoupling means that even as the economy grows, total carbon emissions fall year-on-year. $(7,8)$

With this distinction in mind, the question becomes: is absolute decoupling of economic growth from carbon emissions possible? And can it be done fast enough to prevent catastrophic climate change?

\section{The scale of the challenge}

According to the IPCC, there is a $66 \%$ likelihood that the world can remain under the Paris Agreement target of $1.5^{\circ} \mathrm{C}$ of warming if we emit no more than 420 billion additional tonnes of carbon into the atmosphere, from early 2018.

Humans currently emit about 37 billion tonnes of carbon every year, and that number is still growing. Even the most generous projections suggest that if emissions continue at this rate, the carbon budget will be used up in less than 20 years. 
The rate of decarbonisation that's needed is huge, and far in excess of anything that's been seen previously. Economic growth makes that challenge even harder, as gains in decarbonisation may be outweighed by increases in production and consumption. But green growth advocates insist it's possible.

The IPCC's Special Report, released in October 2018, gives 90 scenarios that would be consistent with limiting warming to $1.5^{\circ} \mathrm{C}$, while also continuing with economic growth. So far, so good. But almost every single one of these scenarios relies on a negative emissions technology called Bioenergy Carbon Capture and Storage (BECCS) that's completely untested at large scales.

BECSS involves growing large plantations of trees, which draw down carbon from the atmosphere, then harvesting and burning them to generate energy. The $\mathrm{CO}_{2}$ emissions from this process are then stored underground. To limit warming to $1.5^{\circ} \mathrm{C}$, this technology would need to absorb 3-7 billion tonnes of carbon from the atmosphere every year. That's at least 2,000 times more than it's currently capable of doing.

In order to absorb that much carbon, an area two to three times the size of India would need to be covered with tree plantations. Think about the difficulty of acquiring that much land, the pressure it would put on other land uses, like food production, and how much natural habitat it could erase.

No one can say that these feats are categorically impossible. But the evidence suggests that the chances of meeting the $1.5^{\circ} \mathrm{C}$ warming target alongside continued economic growth are, at best, highly unlikely. Can we really take this risk - relying on unproven technologies to rescue us from the threat of climate change? Given the consequences of getting the gamble wrong, surely the answer is no. $(9,10)$

Negative emission technologies don't exist at the scale they're needed - and could do more ecological harm than good. Mariusz Szczygiel/Shutterstock

\section{Where does this leave us?}

Proposals for green growth that rely solely on technology to solve the climate crisis are based on a flawed idea. This is, that the limits to the world's physical systems are flexible, but the structure of its economies are not. This seems entirely backwards and more a reflection of the importance of politics and power in determining what solutions are deemed viable, than any reflection of reality.

So society should ask, are these global institutions promoting green growth because they believe it's the most promising way of avoiding climate breakdown? Or is it because they believe it's simply not politically feasible to talk about the alternatives? $(11,12)$

If we can be optimistic about humanity's ability to develop fantastical new technologies to bend and overcome the limits of nature, can't we lend that same optimism to developing new economic structures? Our goal in the 21st century should be creating economies that allow 
people to flourish and grow, even when they don't grow.

\section{From not having kids to battling anxiety: Climate change is shaping life choices and affecting mental health}

Revelle Mast wanted to be an architect when she was a kid. She changed course in high school, deciding to pursue chemical engineering to address the threat of climate change. But, last year, she made another life decision: to go into politics.

"I realized about a year ago that was not feasible on the time scale that climate change is happening," Mast said. "Nine months ago, I quit my engineering job and went full time into political work." (13, 14)

As global warming - the gradual increase in temperature of the Earth's atmosphere-accelerates, people are grappling with the idea that disastrous conditions may appear as soon as 2040. The reality of this potentially existential crisis greatly impacts the way some people, especially those who have dedicated their lives to stopping climate change, make life decisions - whether that's going vegan, living in a certain part of the country or deciding against having children. It even impacts their mental health. $(15,16)$

For some people, ignoring climate change is not an option. It's real, it's happening, and preventing the crisis from getting worse is a driving force in their lives.

\section{Deciding what to do with their lives}

"There's a strong chance that society, as we know, it is going to be in shambles," said Faith Ward, a 19-year-old climate activist with the youth movement Zero Hour. "What position am I going to be in for the sake of leadership?"

Ward is from Plantation, Florida, a city in the thick of the climate crisis because of its coastal location. At Zero Hour's Youth Climate Summit in Miami earlier in July, the team was told to picture a place they consider sacred that is especially threatened by global warming, she said. While others pictured distant nature reserves, Ward was picturing her hometown.

"Everyone else was picturing some place far off," Ward said. "But I was standing there, it wasn't my imagination. I'd pushed that thought down, but just standing there and thinking about it, I broke down crying in front of the group." $(17,18)$

Even though rising sea levels and hurricane intensities frighten her, Ward said the climate crisis has made her determined to stay home and protect her community. Her fight against climate change is personal, she said.

"I don't think any natural disaster could break the emotional ties I have here," Ward said.

Lauren Maunus, also from South Florida in Palm City, was introduced to climate change's harm by observing it in her hometown. In fourth grade, her town was struck by two back-to-back Category 4 hurricanes. At first she saw this as an opportunity to miss school for a month 
and tube down the streets. But she soon realized while her family's house remained unharmed and their car intact, this was not the case for some of her classmates in lower income neighborhoods. $(19,20)$

"With those back-to-back massive storms, I saw injustice even if I didn't have the language for it, and from that point I was always fighting for environmental justice and climate justice," Maunus said. "I couldn't get that image of disparity out of my mind."

Maunus dived deeper into environmental issues in college and learned how the crisis implicates every part of our society. Now, she's a political and legislative coordinator for the Sunrise Movement, a youth-led movement advocating political action on climate change.

Isabella Fallahi, 16, is the communications director for Zero Hour. Fallahi lives in Indianapolis, Indiana, a state that ranks 48th for quality of life and 46th for air quality. She was re-diagnosed with asthma this year because of worsening allergies triggered by climate change, she said.

Fallahi said being personally impacted by climate change's effects has made her even more determined in her activism. $(21,22)$

"I have to go off to college and still won't be able to escape the air quality that has damaged my respiratory system and my lungs for years now," Fallahi said. "It's going to forever play a role in what I do and how I do things."

\section{Deciding to address climate anxiety}

Christene Dejong would be awake at 2 in the morning, panicking over impending environmental "apocalyptic scenarios." $(23,24)$

She was always aware of environmental concerns, the Amherst, Massachusetts, native said.

But after the 2017 Paris Climate Agreement withdrawal coupled with the 2019 U.N. report that says up to 1 million species are at risk of extinction, "some switch flipped and I just started freaking out all the time."

The Paris agreement aims to combat global warming by gradually reducing emissions of greenhouse gases such as carbon dioxide and methane, which come from the burning of fossil fuels such as oil, coal and natural gas. President Donald Trump announced in June that the U.S. would withdraw from the deal. $(25,26)$

A Yale survey released in December found nearly $70 \%$ of Americans are "worried" about climate change, 29\% are "very worried" - up eight percentage points from just six months earlier - and $51 \%$ said they felt "helpless."

This anxiety has gained so much traction in the national consciousness that it is starting to needle its way into popular media. On an episode of the popular HBO drama "Big Little Lies," the daughter of one of the main characters has a panic attack while learning about climate change. $(27,28)$ 


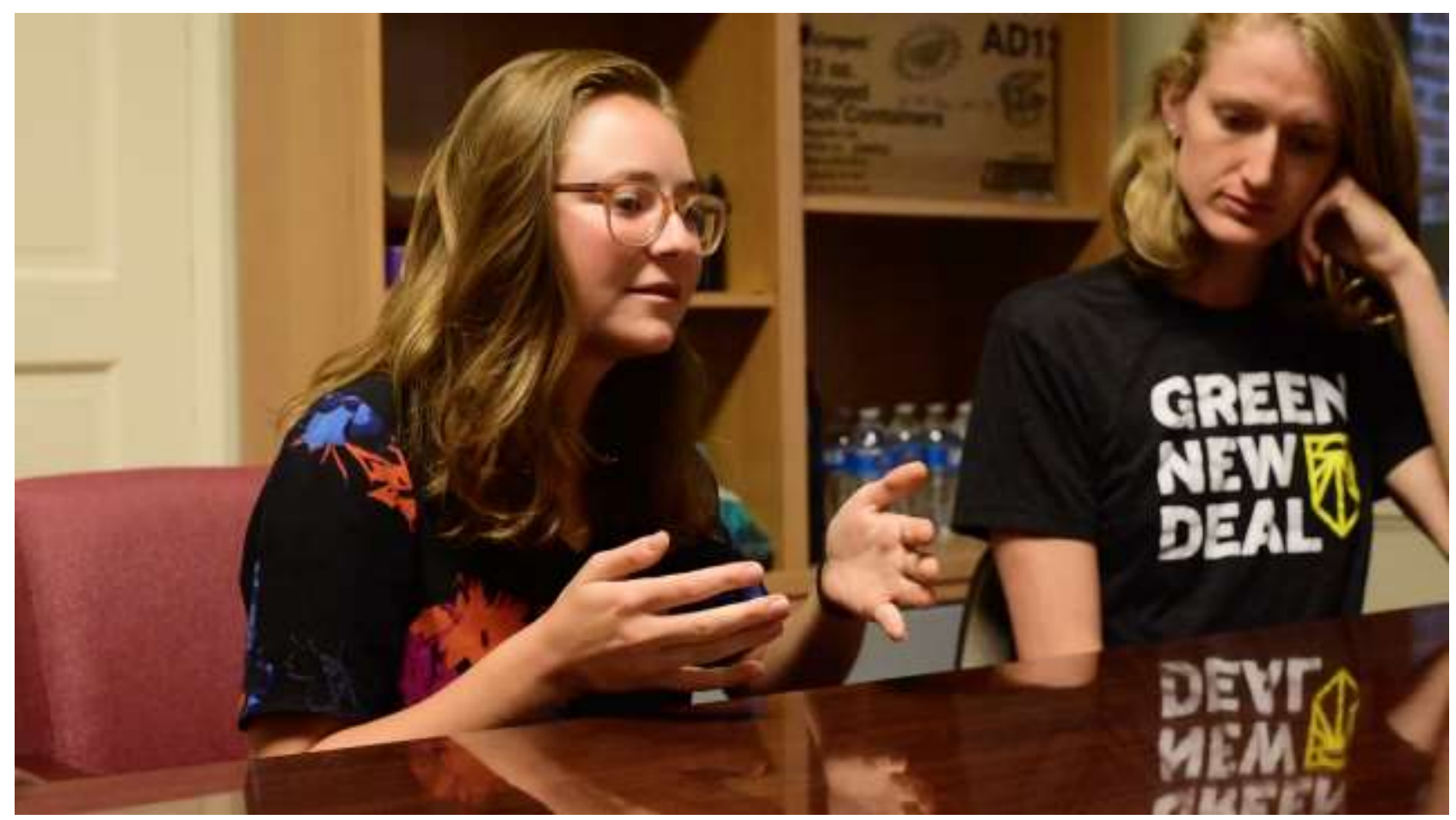

Susan Clayton, professor of psychology at the College of Wooster, said mental health issues surrounding climate change can stem from both climate change events directly experienced and concern about the changing climate in general.

"You don't have to be directly affected by climate change in order to be worried about climate change," she said.

Psychotherapist, ecotherapist and author Linda Buzzell who is from Santa Barbara, California, has struggled with "ecoanxiety" herself.

"I think it's beginning to dawn on us that we're not going to be here very long if our habitat is basically killed off and dying," she said.

This can manifest as trauma from events, post-traumatic stress disorder, compounded stress and depression, or even death by suicide, Clayton said.
She wrote in a study that in some cases, feelings of loss, because of natural disasters or knowledge of climate change impacts, persist for so long and so severely "that individuals have trouble resuming their normal lives."

Chris Paluszeck says his eco-anxiety manifested mostly because of his kids' births - his son was born five years ago and his daughter three - which he says has "been a wake- up call."

"You want to have them inherit a world at least as good as what you had, hopefully better," he said. "But to read about it and understand what's coming our way, it seems like it might not be the case. And that really hit me hard."

Paluszeck, of Burbank, California, has attended meetings of the Good Grief Network, a support group based in Nebraska for people to talk about their climate anxieties. It is known for its 10 step 
model for personal resilience and empowerment.

The founders, Laura Schmidt and Aimee Lewis Reau say that "Good Grief is what happened when we kept digging into these issues" of climate change and anxiety surrounding it. They two are originally from Michigan but moved to Nebraska to work on this project.

Their goals are to make people confront the "collective despair" that is felt by those who feel that climate change is inevitable, as well as "come together in community," according to Reau.

Paluszeck said the Good Grief Network has helped him mitigate the anxiety he feels every day by talking and sharing stories.

"Joining a circle of people that also feel the way you feel really helps you not feel so alone," he said.

Dejong said finding a community with other mothers concerned about climate change hashelped her cope with feelings of panic. She urges others to find the "hundreds of thousands of people who are doing something" about the issue and join their cause. (29, 30)

\section{Deciding to make lifestyle changes}

The first thing Kim Cobb, a climate scientist at the Georgia Institute of Technology, did was start riding her bike to work. Then she replaced her light bulbs, her sister's light bulbs and her parents' light bulbs with LEDs. Her next step was reducing the flying she did by
$35 \%$. She also calls herself an aspiring vegan. $(31,32)$

"After 2016, which brought the heatrelated death of much of the coral reef I've worked at for 20 years and then the election of this administration, I kind of had to find another gear of climate engagement," Cobb said.

She's usually met with amazement when telling people about her lifestyle changes. She's one of the few people in her neighborhood with solar panels on her roof, whose expenses have left her husband "with his jaw on the floor," she said. Cobb noted the government doesn't make it easy for people to lead more climate friendly lives.

"It's not that we're doing a hell of a lot to give people a lot of choice in the matter," Cobb said. "What would it look like if we had really safe bike infrastructure? What would happen if we really subsidized rooftop solar? We would move the market. People want solutions to climate change. People are concerned about climate change. And yet policy is dragging."

To shift policy and systemic change, Cobb has thrown herself into influencing lawmakers, starting in her own community. She was elected traffic chair of her neighborhood's board and said she frequents city hall to advocate for biker safety.

\section{Deciding not to have children}

The decision of whether or not to have children can be tough for activists. 
Some have given up on having kids altogether. British musician Blythe Pepino, 33, created BirthStrike, a group of people who've decided against having kids in the wake of the climate crisis. She's also an activist with the Extinction Rebellion, a movement using civil disobedience to protest climate change inaction.

"Mainly, I want to be an activist," Pepino said. "I'm also afraid for the child I would bring into the world." Like Cobb, Pepino has made climate-related lifestyle changes. She's vegan and she doesn't fly anymore, meaning she probably won't accomplish international recognition as a musician - a fact she has accepted. Pepino says the decision to not have kids became harder to accept, though, when she met her current partner. Mast, who is a trans woman, had to make her decision on having kids when transitioning. She decided against it, and so she didn't bank sperm.

"That was a decision I made when I was 24 that I'm not having kids because the climate can't take it," said Mast, who's from the San Francisco Bay Area. "By not having kids, I can devote that much more of my life toward fixing this crisis." $(33,34)$

\section{Climate change may take a toll on our mental health, too Charli Shield}

Australian psychologist Susie Burke tells the story of a woman who came to her for counseling after having her first child. Not because she was suffering from postpartum depression, but because she was "struggling with the enormity of what she had done." She felt she had brought her child into a "world she knew was going to be a lot harsher and a lot less safe," Burke told Deutsche Welle.

"She came to me when she was overwhelmed by this distress; questioning whether she had done the right thing. The fear she had for his future was really huge."

Burke, who specializes in ecopsychology, treats people suffering mental illness as a result of climate change. She recently set up a free hotline called the "Climate Change Psychological Support Network," where Australians can call a psychologist to talk through their feelings about environmental change. $(33,34,35)$

"One of the very first things people need to do to engage properly with climate change is to acknowledge how they feel about it and talk about it," Burke said.

\section{Eco-anxiety, grief and guilt}

A sense of pervasive loss, devastation and change are endemic to a world afflicted by climate change. Polar ice caps are melting, many animal species are going extinct; the weather is unpredictable and often extreme.

We are increasingly aware of the impacts these changes are having on our physiological health - whether it be as stark as death and injury from extreme weather events, or more insidious harm from the worsening quality of water, air and food. But as the emerging field of eco-psychology reveals, climate change 
takes a significant toll on our mental health, too.

"For people who are hearing and paying attention to what is happening to the climate, it is a huge weight and anxiety and fear," Burke said. Having worked in the field for the past two decades, the psychologist describes observing people with "anxiety and depression, flat moods, helplessness and hopelessness, and anger," as well as "guilt and shame."

\section{A little-known problem}

Although it might seem evident that extreme changes resonate with people on an emotional level, it is not something often talked about. The health of millions of people around the world is already being compromised by global warming. Scientists say it is the major threat of the 21 st century. But there is little emphasis on mental health. "It's a huge gap in the literature," said Ashlee Cunsolo, researcher and director of an institute geared toward sustaining Indigenous culture in Canada. $(30,31)$

For the globe to comprehensively tackle health challenges arising out of climate change, Cunsolo argues mental health must inform policymaking. This, she said, requires "a mass system-wide societal shift" in how climate change is thought about and what the potential long-term impacts might be.

The United Nations Framework Convention on Climate Change includes a section that details the impact from climate change. Consolo notes that it initially conceptualized loss and damage in terms of "infrastructure and the market" when it was written in the 1990s. But it has been adjusted to account for "intangible losses," such as "cultural knowledge, language and place," she said. $(30,32)$

\section{Invit on thin ice}

Cunsolo first observed this aspect of climate change while working in public health with Invits in Eastern Canada. After witnessing rapid changes in their environment - such as melting sea ice and unpredictable weather - these communities expressed a profound sense of "grief associated with loss of place, loss of sea ice, loss of livelihoods," she said.

It was this research that prompted Cunsolo and her colleague, Neville Ellis, who works closely with farmers suffering drought in Western Australia, to create a new category of emotional trauma called "ecological grief." Cunsolo describes this as "the responding mental and emotional pain, stress and sadness" that arises from environmental change.

"The word 'Invit' literally means 'people of the sea ice' - so this is a very deep, existential questioning of humanity," the researcher said." People are really having their foundations impacted by these changes."

Although climate scientists warn that a 1 to 2 degree Celsius temperature increase globally would have devastating effects around the globe - even making some parts of the world inhospitable evidence has shown that Laborador has already surpassed this threshold and is instead looking at a temperature increase of 6 to 8 degrees Celsius. 
The unprecedented loss of sea ice has had an enormous impact on the Invit communities' ability to hunt, travel, and practice their culture, Cunsolo said. "There's a lot of concern for what it means for the future - a lot of anticipatory grief."

\section{Discussion}

In this study, we demonstrate the feasibility of a cell-based assay to investigate the impact of circadian desynchrony on a cellular/molecular level. The use of this model allowed us to comprehensively assess impairments in cell physiology induced by a jet-lag protocol, and it revealed a molecular mechanism that is not only relevant for the role of circadian dysregulation in cancer but also provides a molecular target for chronotherapy. Importantly, we show that the mechanism as well as timeof-day effects of a drug targeting the mechanism are manifest in mouse tumor models. $(30,31)$

The dex synchronization model is used largely to induce free-running circadian oscillations in mammalian cell lines. However, GCs such as dex are also relevant for circadian synchrony in the organism. Besides photic entrainment driven by the SCN, mammalian body clocks can be directly reset by multiple stimuli such as stress, exercise, and nutrition, of which GC hormones released from the adrenal cortex are among the most potent non-photic synchronizers. GC levels exhibit robust daily oscillations, with peak expression in the morning and a trough at night, driven by circadian regulation of GC production by a local clock in the adrenal gland as well as by systemic innervation. GCs mediate circadian responses to various psychosocial stresses, and thus disruption of GC rhythms by shift work or jet lag could be relevant to pathological conditions. Indeed, disruption of daily GC rhythms is even linked to cancer, perhaps related to the inhibitory effects of GC on cell proliferation. These critical roles of GC in normal circadian physiology provide an important rationale for the use of dex to impose CCD in a cell-based model.

Notably, in our circadian transcriptome data, a significant number of genes exhibited circadian cycling in the daily dex-synchronized U2OS cells ( $n=44)$, compared with cycling genes estimated in the same cells after a single dex treatment in a previous report $(n=7)$. This could be primarily due to different experimental and rhythm assessment procedures, for instance, with respect to the measured time points and analysis criteria used in each of the studies. Another possibility for the discrepancy is that the regular rhythmic environment, with daily dex treatment, induced more robust cycling of responsive genes. This is reminiscent of previous circadian gene expression profiling data showing that a large number of genes exhibit diurnal cycling, but not all cycle in free run, nor are all directly clock controlled. Given the robust diurnal fluctuation of $\mathrm{GC}$, it is tempting to speculate that our daily dexsynchronization regimen closely mimics physiological cycling in the presence of light-dark cycles. (30)

Malignant cell proliferation and tumor growth is a major pathological consequence of chronic jet lag. 
Underscoring the link between disrupted clocks and cancer, our unbiased approach, which consisted of characterizing many different cellular functions as well as conducting genomewide RNA-seq to determine how cell physiology is perturbed by circadian disruption, reveals that cell proliferation, along with concomitant changes in gene expression, is the most highly affected function. Our chronic jet-lag protocol results in a dramatic increase in the ratio of oncogenic genes to tumor suppressor genes. Given the tumor suppressive effect of enhanced circadian function in a recent study, we suggest that chronic circadian perturbation tips the transcriptional balance of tumorprogressive and -suppressive genes in favor of promoting tumor survival and proliferation. This explains in part why carcinogen-induced or -injected tumors grow faster under chronic jet lag. We note that clock proteins may also directly regulate tumor suppressors and oncogenic proteins. However, as our chronic jet-lag experiments reported here are performed with cancer cells and induced tumor tissues, we cannot speak to how a jet-lag paradigm would impact nontransformed cells. Also, because not all cancer cells have functional circadian clocks, the proposed mechanism would likely only apply to the subsets of cancers that maintain a clock function.

On the other hand, recent studies have shown that circadian rhythms can be reprogrammed or otherwise affected by tumors or multiple tumor components. For example, lung adenocarcinoma and breast cancer reprogram circadian rhythms in liver metabolism and transcription, respectively. Furthermore, cell cycle-related oncogenes (MYC, RAS) were found to affect the circadian clock. These findings indicate a dynamic bidirectional relationship between circadian disruption and cancer progression. $(34,35)$

Several mitogenic and oncogenic pathways signal to the cell cycle machinery through D-type cyclins. Consistent with this, our transcriptomic analysis reveals extensive up-regulation of upstream signals and downstream transcriptional activators of the cyclin D1 gene in U2OS cells exposed to chronic jet lag and. More interestingly, cyclin DI expression was markedly elevated in tumors, but not in other tissue, in chronically jet-lagged mice. These results suggest that the expression of cell cycle proteins is more sensitive to chronic jet lag in cancerous cells. We note that cyclin D3, another D-type G1 cyclin important for cancer cell survival and progression, was also up-regulated by CCD in our transcriptomic data. Our findings regarding cyclin $D$ corroborate the reported oncogenic role of cyclin $D$ in triggering spontaneous tumors or inducing tumors in response to mitogenic and oncogenic signals [72]. Taken together, these data suggest that cyclin D mediates abnormal tumor proliferation in response to chronic jet lag.

Molecular links between the circadian clock and the cell cycle have been suggested in a few previous studies. For instance, in a murine hepatectomy model, circadian regulation of the G2-M transition was proposed to be driven by clock-controlled expression of Weel G2 
checkpoint kinase (Weel), a key cell cycle inhibitor that phosphorylates and thereby inactivates the CDK1-cyclinB 1 complex. Timely coordination of the G1/S phase is suggested by circadian transcriptional regulation of p21 and p16, which encode inhibitors of cyclindependent kinases, including CDK4/6. In addition, the myelocytomatosis oncogene cellular homolog (Myc) protooncogene is thought to be regulated by BMAL1/neuronal PAS domain protein 2 (NPAS2) (a CLOCK paralogue) action on its E-boxes, which may contribute to enhanced tumor growth in Per2 mutant mice in response to DNA damage. Myc can act through p27(Kipl), another multifunctional CDK inhibitor, to facilitate the activation of CDK4/6. Our in vitro and in vivo data demonstrate that CLOCK/BMAL1 directly regulate cyclin D1, which likely contributes to rhythmic CDK4/6 activity, so multiple circadian mechanisms may converge on CDK4/6. We show also that chronic jet lag alters the phosphorylation of RB, which is the rate-limiting substrate of cyclin D1CDK4/6 in the cell cycle progression. Importantly, RB phosphorylation is predominantly affected at $\$ 807 / 811$, which is a known CDK4/6 site. S807/811 on RB serves as a priming site whose induced phosphorylation releases the tumor-suppressive effect of RB and promotes cell cycle entry, as well as cell survival. In this regard, rescue of RB-null cells (C33A) with RB phospho mutants (S807/811A) significantly blunted but did not completely abrogate the enhanced cell proliferation upon CCD. We speculate that RB-like protein 1 (RBL1, p107), which has structural and functional similarities to RB and is regulated by cyclin
D-CDK4/6 to de-repress E2F activity during G1/S cell cycle progression, could contribute to enhanced cell proliferation upon chronic circadian disturbance. (32)

Emerging cancer therapeutic efforts target $G 1 / \mathrm{s}$ cell cycle progression, with a focus on the development of selective CDK 4/6 inhibitors. For instance, palbociclib (PD0332991, Ibrance; Pfizer) is a potent oral inhibitor of CDK4/6 initially approved by the United States Food and Drug Administration (FDA) for the treatment of metastatic breast cancer in combination with endocrine therapy. Numerous preclinical and clinical studies show that palbociclib has antiproliferative activity in several types of RB-positive tumors, and it is becoming more widely used to treat multiple cancers. Despite the growing clinical use of palbociclib and other CDK4/6 inhibitors such as abemaciclib (Lilly) and ribociclib (Novartis), these drugs are typically prescribed without any time-of-day indications. Our in vitro and in vivo chronopharmacological studies demonstrate that the cyclin D1-CDK4/6RB pathway is a target for chronotherapy, likely because of circadian regulation of the Gl/S phase. This pathway could even be a circadian marker for cancer therapy targeting the $\mathrm{Gl} / \mathrm{S}$ phase.

Pharmacodynamic variability among cancer patients remains a daunting challenge in cancer drug therapy. Our findings strongly suggest that environmental or physiological perturbation of circadian rhythms such as shift work, abnormal sleep timing, or irregular psychosociological stresses can underlie interindividual variability in both 
cancer growth and response to cancer drugs. Circadian disruption may also be relevant for the chronic sleep loss and depression suffered by many cancer patients following diagnosis and treatment. Given this, it is reasonable to expect that resetting of the body clock by scheduled light exposure, mealtimes, or exercise, alongside a carefully timed chemotherapy regimen, would improve antitumor treatment. Taken together, our study provides a mechanism for tumor susceptibility conferred by circadian dysregulation and highlights the importance of judicious application of cancer chronotherapy.

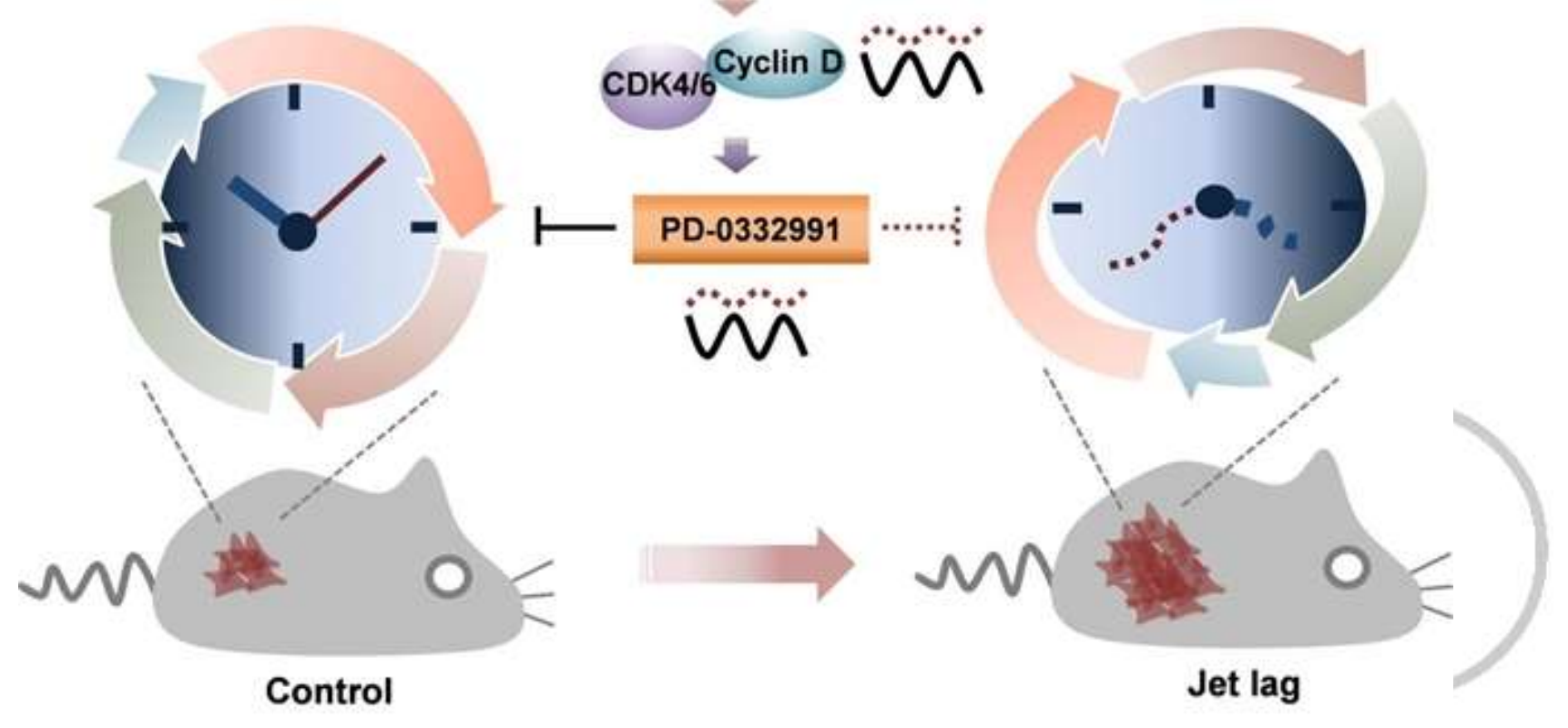

Climate change 'could cause massive economic disruption around the world'

Climate change will cause massive economic disruption around the world as rising seas swamp coastal areas and devastate agriculture, a report has warned.

Researchers led by the International Institute for Applied Systems Analysis (IIASA) assessed the impact of climate change on the world economy, based on different scenarios.
Some countries could face GDP (gross domestic product) loss of up to $12 \%$, scientists warned, with China likely to be among the worst affected.

Disruption to the global economy could be up to $4 \%$, the scientists said depending on whether countries manage to stick to the Paris Agreement, which aims to limit global warming to below $2^{\circ} \mathrm{C}$ compared to pre-industrial levels.

Thomas Schinko, IIASA risk and resilience deputy program director, said, "We found that up to 2050 the global GDP 
losses in both climate futures are significant and similar given the effects of climate change that we are already experiencing. (33)

"However, by 2100, without further mitigation and adaptation and assuming continued sea level rise, projected annual global economy-wide losses can amount to more than $4 \%$.

"With ambitious mitigation and adaptation, the model results show that this number can be reduced to below $0.5 \%$ of global GDP loss, despite the associated costs for adaptation measures and residual impacts. This confirms the importance and economic efficiency of adaptation in the long-term: making sure that coastal communities and their infrastructure are climate-resilient will affect economies across the globe much less than persistent climate impacts in the absence of climate action."

China remains the country with the highest projected relative GDP loss if no further adaptation is undertaken, which is now a factor of 10 higher than it was in 2050.

According to the economic modelling undertaken, annual losses would amount to $9-10 \%$ in a well below $2{ }^{\circ} \mathrm{C}$ scenario, and to $11-12 \%$ under a current mitigation policy scenario.

Other regions with severe economy-wide damages by 2100 under no adaptation are Europe and Japan. $(30,32)$

This week, a former chief scientific adviser to the British government backed the Extinction Rebellion climate change protests as he offered to testify in defence of a group facing trial for gluing themselves to a London airport concourse.
David King, who served as chief scientist under prime ministers Tony Blair and Gordon Brown, said Extinction Rebellion like Swedish climate activist Greta Thunberg - was playing a vital role in raising visibility around the climate crisis.

\section{"Climate change represents the greatest threat that humanity, as a whole, has ever had to manage," King said in a prepared witness statement.}

Britain saw a surge in climate activism last year with the civil disobedience group occupying sites in central London, blocking roads and targeting financial institutions and government buildings.

More than 1,100 protesters have been sentenced so far, with most receiving conditional discharges. King, a professor of climate change, arrived at court saying he was ready to give evidence on their behalf, but the judge threw out the case due to a prosecution administrative error.

\section{Russian government to 'use the advantages' of climate change}

A Siberian explorer near the tusks of a 23,000-year-old mammoth that rests in a block of ice 200 miles $(320 \mathrm{~km})$ from the Russian city of Khatanga - Reuters. Russia is planning to "use the advantages" of warmer temperatures brought about by climate change, according to a document published by the government at the weekend.

The report notes increased opportunities for navigation and trade as ice melts in the Arctic, an area where Russia has also boosted its military presence in recent years.

The two-year, "first stage" plan lists other advantages including decreased spending on heating over the winter and 
the possibility of new areas available for farming.

But the 30-point paper also focuses on the risks of climate change and the dangers it poses to public health, animal environments and the Russian permafrost. (35)

"The consequences of (climate change) are having a significant and increasing impact on the economic and social development of the country, its conditions for life and people's health," according to the document signed by Prime Minister Dmitry Medvedev.

Russia is warming on average 2.5 times quicker than the rest of the planet, the report said, adding that the country's industry, transport and agriculture would have to adapt to these changes.

The government said it would plan for crisis scenarios including evacuations in the case of natural disasters, and make sure climate change was taught in schools.

The publication comes after Moscow experienced its warmest December on record, with authorities dumping artificial snow in Red Square ahead of New Year celebrations.

Normally the capital spends millions of pounds a year and employs tens of thousands of people to keep roads and pavements free of snow.

President Vladimir Putin has questioned the scientific consensus that global warming is caused by human activity, saying at a recent press conference that "nobody knows the origins of global climate change".

But he said that rising temperatures could have "very serious" consequences from
Russia. Moscow has formally adopted the Paris climate accord and criticised the US President Donald Trump's decision to withdraw from the deal. $(34,35)$

\section{CONCLUSIONS}

We have asked the Permanent Mission of Sweden to the United Nations to introduce a new initiative on illegalization of the Sonic and Dazzling Weapons (Bioacoustic deterrents) with formulation of a new International Treaty on Prohibition of the use of the Sonic Weapons. They must be prohibited because are causing Carcinogenesis and Death of Humans. We here in my home in Dubnik h. n. 317318, Slovakia have a new tragic case when one of the neighbor living nextdoor Tomas Pinke and his son Sebastian Pinke reportedly were misused the Bioacoustic deterrents against Mária Deáková (66) who had in 3 weeks got a carcinogenesis of liver and from this reason has at July 17, 2018 died!

We have a growing numbers of data which are showing, that this FCO can be a Psychological Weapon of the "underworld" with help of some Foreign Power geographically situated relatively close to Slovakia, for example Russia. In our region is placed a company named 94135 AT Dunaj Dubnik, Slovakia, lead by Rudolf Ertinger (car No.: NZ 683 ER), which can be suspected from close contacts with Russian firms and which can be also suspected from misuse of the sonic and dazzling weapons. Similarily, the company AT Dunaj Dubnik probably may have business exchange with Russian firms violating the European Union's (EU) Sanctions Regime (for example in May 15 , 2019 they have sent a big TIR car to Russia,etc.), soften misusing production of artificial rain making, by which is partly destroying the Climate in the region of 
District Nove Zamky, Slovakia, etc. From above reasons our question is if the responsible official organs of Slovakia has some relevant knowledge or agreements on these dazzling weapons if using the International Space Station?

\section{REFERENCES}

1. Ch. D. Fiorillo et al., Science 299, 18981902 (2003)

2. K. R. Riderinkhof, W.P.M. van den Wildenberg, Science 307 1059-1060 (2005)

3. C.K. Machens et al., Science 307, 1121 (2005)

4. J.W. Brown, T.S. Braver, Science 307 , 1118 (2005)

5. B. Knutson et al., The Journal of Neuroscience, 25(19) 4806-4812 (2005)

6. W. Schulz, Current Opinion in Neurobiology, 14, 139-147 (2004)

7. E. Bieberich, Structure in human consciousness: A fractal approach to the topology of the self preceiving an outer world in an inner space. Medical College of Virginia Campus of Virginia Commonwealth University, Richmond, VA, (2002)

8. B. Baars, In the theatre of consciousness. J. of Consciousness Studies 4, 292-309 (1997)

9. B. Baars, Cognitive Theory of Consciousness. Cambridge U. P., New York (1988)

10. A. Nieder, et al. Representation of the quantity of visual items in the primate prefrontalcortex. Science 297, 1708-1711 (2002)

11. S. Dehaene, et al. Sources of mathematical thinking: behavioral and brain-imaging evidence. Science 284, 970-974 (1999)

12. S. Dehaene, The neural basis of the Weber-Fechner Law: a logarithmic mental number line. Trends in Cognitive Sciences Vol.7, No. 4 (2003)

13. S. Dehaene, $M$. Kerszberg, and J. $P$. Changeux, A neuronal model of a globalworkspace in effortful cognitive tasks. PNAS, Vol. 95, Issue 24 (1998)

14. J. McDermott, Nature Neuroscience, Vol. 5, No. 9, (2002)

15. G. Tononi, G. Edelman, Consciousness and Complexity. Science, 282 (1998)

16. G. Tononi, An information integration theory of consciousness. BMC Neuroscience, Volume 5 (2004)

17. M. Raichle, The neural correlates of consciousness: an analysis of cognitive skill learning. Philos Trans R Soc Lond B Biol Sci, 353 (1998)

18. K. Gödel, What Is Cantor's Continuum Problem ? The American Mathematical Monthly 54 (1947)

19. E. Wigner, in Quantum Optics, Experimental Gravitation, and the MeasurementTheory. P. Meystre, N. Scully, eds., Plenum, New York (1983)

20. I. Prigogine, The End of Certainty. Time, Chaos and the New Laws of Nature. New York, The Free Press (1997) 
21. G. Mikhailovsky, Biological Time, its Organization, Hierarchy and Representation by Complex Values. EReports, Moscow (2000)

22. N. Kobozev, Investigations in the Field of Thermodynamics and Thinking Processes. Moscow (in Russian) (1971)

23. J. Wheeler et al., Interference in Phase Space. Annalen Der Physik, Band 48, Heft 7. 423-502 (1991)

24. S. Dehaene, J. P. Changeux, Ongoing Spontaneous Activity Controls Access to Consiousness: A Neuronal Model for Inatentional Blindness, PLOS Biology, Volume 3, Issue 5, (2005).

25. Editorial (2003) Anterior cingulate cortex regulation of sympathetic activity. Brain, 126

26. Carter C. S. (1998) Anterior Cingulate Cortex, Error Detection, and the OnlineMonotoring of Performance. Science, Vol. 280.

27. Kaya Yurieff: Drought woes ? This tech can make it rain. CNN Money, June 18,2018

28. Yol Lee at al., Gl/s cell cycle regulators mediate effects of circadian dysregulation on tumor growth and provide targets for timed anticancer treatment. Plos Biology, April 30,2019 https://doi.org/10.1371/journal.pbio.30002 $\underline{28}$

29.

https://vaaju.com/czechrepubliceng/inv estigation-at-the-russian-space-

organization-billion-hasbeen-stolennovinky-cz/ - May 16, 2019 World

30. Skopec R, I.: (2017) An Explanation of Biblic Radiation: Plasma. Journal of Psychiatry and Cognitive Behavior, July 2017.

31. Skopec R, II.: (2018) Artificial hurricanes and other new Weapons of Mass Destruction. International Journal of Scientific Research and Management. Volume 5, Issue 12, Pages 7751-7764, 201.

32. Skopec R, III. (2015) Intelligent Evolution, Complexity and SelfOrganization. Euro Quantology 13: 299303.

33. Skopec R, IV. (2016) Translational Biomedicine and Dichotomous Correlations of Masking. Translational Biomedicine Vol. 7, No. 1: 47.

34. Skopec R, V. (2018) All Humans are Pre-Programmed to Innate Carcinogenesis throug he CoOccurrence of Metastases Caused by Quantum Entanglement Entropy. Archive of Oncology and Cancer Therapy Vol. 1, Issue 2, PP-29-36

35. Skopec R, VI. (2019) Naphazoline Nitrate Treat The Frey Effect Of Microwave And the Sonic Weapon's Damages In Human's Internal, Endogenous Organs. International Journal of Research in Medical and Basic Sciences Volume 5, Issue 1, January 2019, PP-28-38. 